\title{
How we transform industrial organic waste into vermicompost and champion environmental sustainability
}

\author{
M. Quintern ${ }^{1}$, M. Morley ${ }^{2}$, B. Seaton ${ }^{2}$ \& R. Hamilton ${ }^{3}$ \\ ${ }^{1}$ Quintern Innovation Ltd., Consulting, New Zealand \\ ${ }^{2}$ MyNOKE Industrial Vermicomposting, Noke Ltd., New Zealand \\ ${ }^{2}$ Oji Fibre Solutions Ltd., Kinleith Paper Mill, New Zealand \\ ${ }^{3}$ Fonterra Co-operative Group Ltd., New Zealand
}

\begin{abstract}
The traditional means of disposing of processing waste to landfill is receiving close scrutiny due to high capex and opex costs and negative environmental impacts. Increasingly stringent legislation means communities and industries are seeking the security of alternative solutions when planning their long-term organic waste disposal strategies. Important to these are excellence in environmental performance, ecological sustainability and to cost effectiveness. Vermicomposting technologies achieve this through the conversion of wet organic waste to a nutrient rich, safe fertiliser for sustainable land utilisation. Vermicomposting is highly cost effective for industrial and municipal organic waste streams. MyNOKE is currently vermicomposting 30,000 tonnes per year of co-decanter dewatered waste activated sludge (WAS) and dissolved air flotation (DAF) sludge from Fonterra milk processing plants in New Zealand. The sludge is blended with 50,000 tonnes of several pulp and paper mill sludge's from Oji Fibre Solutions Paper Mills for vermicomposting. The product, some 20,000 tonnes of vermicast, is land applied to dairy pasture and maize land. As a result, productivity, soil water efficiency, and nutrient uptake are increased. Plant available water holding capacity, root density, and root depth reduces the risk for nitrate nutrient leaching when applied as effluent or mineral fertiliser. The new vermicomposting operation is integrated into a Fonterra owned 1,600 ha farm. The Noke vermicomposting process developed by Quintern has grown from vermicomposting 2,000 tonnes of sludge in 2008 to 200,000 tonnes in 2015. Keywords: vermicomposting, pulpmill solids, milk sludge, land utilisation.
\end{abstract}




\section{Organic waste resources}

Within the central North Island region of New Zealand, the primary economic industries are dairying and timber processing. The resultant organic 'waste' resources originating from these industries have traditionally, mostly been disposed of to landfill. More recently these valuable organic resources have been processed using proprietary vermicomposting technologies, which are presented and discussed in this paper.

\subsection{Milk plants waste}

Fonterra Co-operative Group Ltd. (Fonterra) operates a number of milk plants in the central North Island region of New Zealand. These processing results in the production of some 30,000 tonnes of various organic waste, which had previously only been partially land applied. Some of the organic waste sludge has been disposed of to landfill.

\subsubsection{Waste activated sludge}

Waste activated sludge (WAS) with a solids content of approximately $0.45 \%$ is produced at various Fonterra milk plants in the Waikato Region. The result of the activated sludge biological treatment of site waste. WAS is thickened by decanters at two sites to approximately $15 \%$ solids to reduce transportation costs and to achieve a solid, spadeable product. Typical analysis of the WAS from the two sites are given in Table 1.

\subsubsection{Decanted dissolved air flotation sludge}

Wastewater is introduced into continuously operated dissolved air flotation (DAF) process, where larger particles including fat and proteins are extracted through a DAF process. The particles attach to the air bubbles and float to the surface as a DAF sludge and is mechanically skimmed off. The sludge is decanted prior to transportation to the vermicomposting operation. Nutrient contents (Table 1) are significantly lower than those of the WAS. At both the Te Rapa and the Waitoa sites, DAF sludges are co-dewatered with waste activated sludge.

\subsection{Pulp and paper mill organic waste}

Oji Fibre Solutions Ltd. (Oji) operates four pulp and paper mills located in New Zealand's North Island. All four sites produce organic waste generally described as pulpmill solids or sludges. The fibrous pulpmill solids are blended with the Fonterra milk plant sludges. The characteristics of pulpmill solids can be highly variable depending upon the source of fibre e.g. from wood chips or recycled cardboard or paper, the particular pulp mill wastewater treatment processes used and the sludge separation technology. 
Table 1: Characteristics of waste activated sludge (WAS) and anaerobic sludge from various Fonterra milk plants in Central North Island New Zealand.

\begin{tabular}{|c|c|c|c|}
\hline Parameter & \multicolumn{2}{|c|}{$\begin{array}{c}\text { WAS sludge } \\
\text { decanted }\end{array}$} & $\begin{array}{c}\text { Anaerobic } \\
\text { sludge }\end{array}$ \\
\hline Milk plant & Waitoa & Te Rapa & Tirau \\
\hline Dry matter (\%) & 14.1 & 16 & 13 \\
\hline Carbon $(\%)$ & 40 & 43 & 5.6 \\
\hline Nitrogen $(\%)$ & 7.2 & 6.6 & 1.5 \\
\hline $\mathrm{C} / \mathrm{N}$ ratio & 5.6 & 6.5 & 3.7 \\
\hline $\mathrm{pH}$ & 6.2 & 5.8 & 7.7 \\
\hline Phosphorus (mg/kg) & 16,700 & 18,700 & 6,400 \\
\hline Sulphur (mg/kg) & 6,900 & 9,000 & 850 \\
\hline Potassium (mg/kg) & 8,300 & 9,800 & 1,850 \\
\hline Calcium (mg/kg) & 10,600 & 13,500 & 56,000 \\
\hline Magnesium (mg/kg) & 3,000 & 2,700 & 1,030 \\
\hline Sodium $(\mathrm{mg} / \mathrm{kg})$ & 3,600 & 4,900 & 720 \\
\hline Boron $(\mathrm{mg} / \mathrm{kg})$ & 75 & 54 & 1,45 \\
\hline Arsenic (mg/kg) & $<1.0$ & $<5$ & 0.51 \\
\hline Chromium (mg/kg) & 5 & 7 & 0.67 \\
\hline Cadmium (mg/kg) & $<0.1$ & $<0.3$ & 0.03 \\
\hline Copper (mg/kg) & 6 & 7 & 1.38 \\
\hline Lead $(\mathrm{mg} / \mathrm{kg})$ & 1.4 & 0.8 & 0.45 \\
\hline Mercury $(\mathrm{mg} / \mathrm{kg})$ & $<0.1$ & $<0.3$ & $<0.002$ \\
\hline Nickel (mg/kg) & 3 & $<5$ & 1.16 \\
\hline Zinc $(\mathrm{mg} / \mathrm{kg})$ & 71 & 67 & 53 \\
\hline
\end{tabular}

\subsubsection{Pulp and paper sludge from Kinleith Pulp and Paper Mill}

Losses to the pulp and paper mill's wastewater systems from routine cleaning of the pulp and paper machine, average around $15 \mathrm{t} / \mathrm{d}$ (dry basis) of rejected fibre material. This product is referred to as 'primary solids' and is removed in the primary clarifier. The pulp and paper mill's wastewater treatment system produces approximately $12 \mathrm{t} / \mathrm{d}$ (dry basis) of secondary biological solids from the oxidation ponds which are combined with the primary solids prior to being pumped into two gravity-dewatering ponds. Table 2 gives an overview of the characteristics of the primary and secondary solids from Kinleith Pulp and Paper Mill. By blending the different solids the limits for organic certification are met and an organic certified product is produced. The process of producing the pulp and paper sludge from the Kinleith Pulp and Paper Mill is described in more detail by [1].

\subsubsection{Recycled paper solids from Kinleith Pulp and Paper Mill}

The recycled paper solids show similar carbon and nitrogen concentrations to the primary solids. The slightly higher metal concentrations of the recycled paper 
solids (Table 2) compared to the primary pulp and paper mill sludge are still well below the limits for safe land application [3].

\subsubsection{Pulp and paper solids from Tasman Pulp and Paper Mill}

At Tasman Mill, the primary pulp and paper solids are separated in the wastewater treatment plant clarifier by adding a polymer to coagulate the solids which are then de-watered mechanically resulting in a much dryer product than the pulp and paper solids from the sedimentation ponds at Kinleith Mill (Table 2). The pulp and paper solids are generated in a continuous flow process, which enables a consistent supply to the vermicomposting operation.

Table 2: $\quad$ Characteristics of pulp and paper mill sludge and recycled paper solids from various Oji Fibre Solutions' pulp and paper mills in New Zealand.

\begin{tabular}{|c|c|c|c|c|}
\hline Parameter & $\begin{array}{c}\text { Primary and } \\
\text { secondary } \\
\text { solids }\end{array}$ & $\begin{array}{c}\text { Recycled } \\
\text { paper solids }\end{array}$ & $\begin{array}{c}\text { Primary } \\
\text { solids }\end{array}$ & $\begin{array}{c}\text { Limits } \\
\text { organic } \\
\text { certification* }\end{array}$ \\
\hline Pulp and paper mill & \multicolumn{2}{|c|}{ Kinleith } & Tasman & \\
\hline Dry matter (\%) & 17.8 & 26.9 & 34.1 & \\
\hline Carbon (\%) & 37.6 & 37 & 29.7 & \\
\hline Nitrogen (\%) & 0.5 & 0.17 & 0.4 & \\
\hline C/N ratio & 75 & 217 & 75 & \\
\hline $\mathrm{pH}$ & 7.4 & 6.9 & 7.9 & \\
\hline Phosphorus (mg/kg) & 509 & 153 & 939 & \\
\hline Sulphur $(\mathrm{mg} / \mathrm{kg})$ & 3,200 & $<5,000$ & 1,321 & \\
\hline Potassium $(\mathrm{mg} / \mathrm{kg})$ & 1,060 & 240 & 2,180 & \\
\hline Calcium $(\mathrm{mg} / \mathrm{kg})$ & 24,200 & 58,900 & 114,900 & \\
\hline Magnesium $(\mathrm{mg} / \mathrm{kg})$ & 2,440 & 1,900 & 2,120 & \\
\hline Sodium $(\mathrm{mg} / \mathrm{kg})$ & 1,130 & 820 & 3,640 & \\
\hline Boron $(\mathrm{mg} / \mathrm{kg})$ & 0.28 & $<50$ & 20 & \\
\hline Arsenic $(\mathrm{mg} / \mathrm{kg})$ & 1.0 & $<5$ & 2.6 & 20 \\
\hline Chromium $(\mathrm{mg} / \mathrm{kg})$ & 2.9 & 7 & 62 & 150 \\
\hline Cadmium $(\mathrm{mg} / \mathrm{kg})$ & 0.1 & 0.2 & 0.26 & 1.0 \\
\hline Copper $(\mathrm{mg} / \mathrm{kg})$ & 9 & 46 & 55 & 60 \\
\hline Lead $(\mathrm{mg} / \mathrm{kg})$ & 1.72 & 15.2 & 5.0 & 250 \\
\hline Mercury $(\mathrm{mg} / \mathrm{kg})$ & 0.04 & $<0.3$ & $<0.11$ & 1.0 \\
\hline Nickel $(\mathrm{mg} / \mathrm{kg})$ & 1.3 & 5 & 6.1 & 60 \\
\hline Zinc $(\mathrm{mg} / \mathrm{kg})$ & 43 & 77 & 63 & 300 \\
\hline
\end{tabular}

$*[2]$

\section{Industrial vermicomposting in New Zealand}

The first laboratory scale vermicomposting trials using paper waste as a carbon source and blending agent for nutrient rich organic waste have been published by 
[4]. From the 1990's scientists started using pulp and paper mill sludge also referred as pulpmill solids for vermicomposting as bulking agents [5-10]. Vermicomposting of purely pulpmill solids has not been conducted at any significant scale because the wide $\mathrm{C} / \mathrm{N}$ ratio of pulpmill solids makes this product unsuitable for vermicomposting. Laboratory trials have shown that best reproduction of earthworms is achieved when the $\mathrm{C} / \mathrm{N}$ ratio is adjusted to 25 with nitrogen rich waste streams $[8,11,12]$. Various industrial organic waste have been studied for the past 40 years using vermicomposting technology to produce a high quality soil conditioner or fertiliser [13]. Paper waste with a $\mathrm{C} / \mathrm{N}$ ratio of up to 200 and higher were used as a carbon rich blending agent for nutrient rich waste such as biosolids, food waste [4, 14], manure [14], and other industrial waste [15]. In recent years, Quintern et al. have demonstrated that a sub-optimal $\mathrm{C} / \mathrm{N}$ ratio in the earthworm feedstock can be successfully applied in commercial vermicomposting operations and that nitrogen sources captured from the wastewater treatment plant of a pulpmill can be used as nitrogen source for blending with primary pulpmill solids [16-18]. Vermicomposting of DAF sludge from milk processing industries in combination with pulpmill solids has first been studied and published by [19].

Industrial scale vermicomposting of sludge from Oji's pulp and paper mills and other industrial and municipal organic waste streams commenced in 2007 and currently totals 150,000 t/a $[1,16,17,20,21]$. In 2010 Noke Ltd. undertook feasibility studies on commercial vermicomposting of the organic waste stream from pulp and paper industries in combination with dewatered WAS and DAF sludge from Fonterra's milk plants. The aim was to produce a valued added product, vermicast, for beneficial land utilisation. In 2014 Noke Ltd established the efficacy of operating as a full-scale vermicomposting operation and a new site is being developed to receive only these products. This site commenced operating at full industrial scale in September 2015 with a capacity of 70,000 t/a.

\subsection{Vermicomposting process: general}

Thermophilic composting of wet organic sludge with little or no structure as well as wet pulpmill solids with a wide $\mathrm{C} / \mathrm{N}$ ratio proves both difficult and economically challenging. Both organic waste require either mixing with suitable agents to provide oxygen flow or require adding nutrients, mainly nitrogen and phosphorus for rapid decomposition. Thermophilic composting requires mechanical turning thus adding complexity and costs to the process. The high temperatures achieved through the thermophilic process can create significant odour issues, which can be problematic if processed close to populated areas. Thermophilic composting achieves a volume reduction of approximately $1 / 3$.

Vermicomposting is a mesophilic process, which uses epigeic compost earthworms to ferment and decompose organic matter producing a specific earthworm casting called vermicast or vermicompost [13]. Compost worms can 'operate' in moist conditions between 60 to $90 \%$ depending on the structure of the feedstock, so no pre drying is required. Vermicomposting requires no mechanical turning since the feedstock waste is applied in smaller quantities as 
earthworms are mixed with the feedstock through their activity. This action is described as 'bio-turbation' in soil science or could be described as 'vermiturbation' in the process of vermicomposting. During the digestion of the organic waste a volume reduction of up to $80 \%$ can be achieved, this reduces transportation costs of the vermicast to its end users.

\subsection{Vermicomposting technology used in New Zealand}

The vermicomposting technology developed by Quintern Innovation Ltd. is based on the Windrow Vermicomposting System described as low-technology vermicomposting systems [22]. Windrow vermicomposting technology in general is characterised as low capital expenditure (CAPEX) and easy to manage. The drawbacks of conventional Windrow Vermicomposting Systems are a large footprint, labour-intensive, slow processing time, considerable nutrient losses, and need for separation of earthworms from vermicompost. Most of these drawbacks have been resolved by Quintern (Table 3). The key improvements have been achieved by avoiding continuous feeding practices in order to reduce labour costs and processing time. The footprint / net production ratio for vermicomposting has been significantly reduced by minimising the nonproductive areas of the vermicomposting site. The Quintern Windrow Vermicomposting Technology has been developed and proven over the last decade and is successfully operating at an economic industrial scale.

\subsection{Integrated vermicomposting in farm management systems}

To manage the nutrient losses, such as leaching and gaseous losses from vermicomposting sites, the $\mathrm{C} / \mathrm{N}$ ratio of the feedstock is carefully adjusted, which reduces the potential of enriching the underlying topsoil with nutrients and humic acids. Operating at the same location over multiple years could create a hot spot of nutrient loss into the soil ecosystem. To address this potential risk the author adopted the strategy of integrating vermicomposting into farm and forest management practices. Similar to integrating outdoor pig ranging, with extreme high nutrient accumulation in hot spots, the vermicomposting sites will rotate either on the farm $[23,24]$ or within the forest. After a certain time of vermicomposting on one specific site the vermicomposting windrows will be placed on a new paddock or forest block. On the former vermicomposting site the vermicast will be harvested and a so-called 'catch crop' with high nutrient demand, such as maize, will be planted. In forest management systems the new plantation benefits from the vermicast residues as the demand for nutrient of trees is highest in the first years of plant growth.

\subsection{Vermicast}

Vermicast and vermicompost are used in the literature often synonymously. In New Zealand vermicast is defined as mature pure earthworm casting whereas vermicompost may contain some material that has not been processed by compost worms [25]. There are hundreds of references characterizing 
Table 3: Characteristics of the Quintern Windrow Vermicomposting Systems in comparison to conventional windrow vermicomposting systems described by [22].

\begin{tabular}{|c|c|c|}
\hline & Quintern vermicomposting & Conventional vermicomposting \\
\hline \multirow[t]{6}{*}{ Benefits } & Low CAPEX* & Low CAPEX* \\
\hline & Easily managed & Easily managed \\
\hline & $\begin{array}{l}\text { Not labour intensive } \\
\text { (mechanised) }\end{array}$ & \\
\hline & Reduced footprint & \\
\hline & $\begin{array}{l}\text { Retention of nutrients through } \\
\text { wider } \mathrm{C} / \mathrm{N} \text { ratio }\end{array}$ & \\
\hline & \begin{tabular}{|l|} 
Harvesting vermicompost \\
without earthworm separation
\end{tabular} & \\
\hline \multirow[t]{5}{*}{ Drawbacks } & & Labour-intensive \\
\hline & & Large footprint \\
\hline & $\begin{array}{l}6 \text { to } 12 \text { months processing } \\
\text { time }\end{array}$ & 6 to 16 months processing time \\
\hline & & $\begin{array}{l}\text { Loss of nutrient through leaching } \\
\text { and volatilisation }\end{array}$ \\
\hline & & $\begin{array}{l}\text { Impossible to harvest } \\
\text { vermicompost without earthworm } \\
\text { separation }\end{array}$ \\
\hline
\end{tabular}

*Capital expenditure.

vermicompost in relation to the degree of earthworm activity, vermicomposting technology used, and the parent waste or 'feedstock' used. Arancon and Edwards [26] provide a review of the recent findings of beneficial use of vermicast.

In comparison to commonly advised vermicomposting technology, the vermicast produced in this commercial operation has received a much larger portion of fibrous and carbon rich feedstock source as a blending agent. As a result the vermicast has a more advanced peaty structure with lower nitrogen content and therefore a slightly wider $\mathrm{C} / \mathrm{N}$ ratio. This provides the MyNOKE vermicast with various advantages when applied in nutrient sensitive ecosystems, which are lacking in soil humus required for maintenance of a high nutrient and water holding capacity. Specific characteristic of the vermicast are described in Table 4.

\section{Beneficial land utilisation of vermicast in New Zealand}

\subsection{Application of vermicast}

Vermicast is applied in bulk to various crops at rates of $2.5 \mathrm{t} / \mathrm{ha}$ to pasture, $10 \mathrm{t} / \mathrm{ha}$ to kiwi-fruit orchards, and up to $20 \mathrm{t} / \mathrm{ha}$ to maize and to other crops 
according to the specific soil quality and nutrient demand of the crop. Screened vermicast can be applied with standard compost or manure spreaders.

Table 4: $\quad$ Characteristics of $\mathrm{MyNOKE}^{\circledR}$ vermicast produced from mixed Oji's pulp and paper mill sludge and waste activated sludge from Fonterra's milk processing plants in New Zealand.

\begin{tabular}{|c|c|c|}
\hline Parameter & $\begin{array}{c}\text { MyNOKE }^{\circledR} \\
\text { vermicast }\end{array}$ & $\begin{array}{l}\text { Limits organic } \\
\text { standard* }\end{array}$ \\
\hline Dry Matter (\%) & 49.0 & \\
\hline Organic matter $(\%)$ & 39.6 & \\
\hline Carbon $(\%)$ & 21 & \\
\hline Nitrogen $(\%)$ & 1.6 & \\
\hline $\mathrm{C} / \mathrm{N}$ ratio & 13.5 & \\
\hline $\mathrm{pH}$ & 7.0 & \\
\hline Phosphorus (mg/kg) & 4,720 & \\
\hline Sulphur (mg/kg) & 5,100 & \\
\hline Potassium $(\mathrm{mg} / \mathrm{kg})$ & 1,055 & \\
\hline Calcium (mg/kg) & 136,100 & \\
\hline Magnesium (mg/kg) & 2,060 & \\
\hline Sodium (mg/kg) & 2,180 & \\
\hline Boron $(\mathrm{mg} / \mathrm{kg})$ & 23 & \\
\hline Arsenic (mg/kg) & 6.2 & 20 \\
\hline Chromium (mg/kg) & 23 & 150 \\
\hline Cadmium (mg/kg) & 0.4 & 1.0 \\
\hline Copper (mg/kg) & 39 & 60 \\
\hline Lead (mg/kg) & 38 & 250 \\
\hline Mercury (mg/kg) & 0.08 & 1 \\
\hline Nickel (mg/kg) & 12 & 60 \\
\hline Zinc $(\mathrm{mg} / \mathrm{kg})$ & 174 & 300 \\
\hline
\end{tabular}

$*[2]$

\subsection{Benefits to plant growth}

Vermicast produced by compost earthworms (Eisenia foetida) contains humic substances described as humic acids, humates, gibberelins, auxins, 3-indole acetic acid, and various other substances. These humic substances promote plant growth in multiple ways starting with faster germination [9, 27-29], increased root development of more and longer lateral and vertical roots, increased area of root hairs and even higher root activity [30-39]. Increased root area, root growth 
depth, and activity leads to increased nutrient uptake and access to more available soil water during drier seasons.

Positive effects were measured in higher numbers of blossoms, flowers, and fruits, increased photosynthesis which overall leads to higher yields [36, 37, 40], and fruit harvests [41]. Recent studies have shown that vermicast has the potential to suppress plant diseases and to control pests such as insects and nematodes [42-48].

\subsection{Benefits to soils}

The beneficial uses of vermicompost to various crops and forests on different soils have been widely documented. Little is known about the continuous application of vermicast on intensive dairying land, especially on pasture and on intensive monoculture maize cropping systems. Intensive dairy farming is currently criticised for increased nitrate leaching and phosphate runoff. Improved topsoil functions in regards to water and nutrient retention would most likely mitigate nutrient losses, such as nitrate in the groundwater. Higher humus content and more intense root systems would improve soil function, as well as increasing nutrient uptake including nitrogen. Intensive maize cropping may lead to a reduction in soil organic matter and therefore carbon loss from these soils [49]. In a recent trial, vermicast applied at a rate of 20t/ha and at a constant nitrogen fertiliser application rate of $400 \mathrm{~kg} \mathrm{~N} / \mathrm{ha}$ has increased the production of maize silage by 3 to $5 \mathrm{t} /$ ha dry matter. The shoot to root $(\mathrm{S}: \mathrm{R})$ ratio for maize is 5.6 [50] and would increase the root production by 0.54 to $0.89 \mathrm{t} / \mathrm{ha}$ dry matter. In addition to the extra humus accumulation through extra root growth, carbon is applied at a rate of $2.06 \mathrm{t} / \mathrm{ha}$.

\section{Outlook}

Vermicast application to soil has the potential to mitigate nitrate losses, increase soil organic matter directly as a carbon source and indirectly by increasing root production.

Vermicomposting of combined industrial and municipal organic waste offers multiple benefits on the carbon footprint for industry, the community and for the agribusiness sectors. Of significance is the reduction in greenhouse gas emissions originating from the land filling of organic waste and the avoidance of the high economic penalties associated with the design, construction and ongoing monitoring of landfills. For the farming and horticulture sectors, soil carbon would be increased and higher carbon sequestration by increasing root mass and crop yields. A reduction in mineral fertiliser application would reduce the carbon footprint and a better soil structure would reduce nitrous oxide $\left(\mathrm{N}_{2} \mathrm{O}\right)$ emissions from pastoral soils. 


\section{Acknowledgements}

The authors would like to thank Jonathan Stevenson and his team as well as Tim Ellingham for their support in establishing the commercial vermicomposting operation. Ed Mercer and Craig Andrews for supporting all trials allowing this project to come so far. Barry Campbell for discussion around implementing the industrial scale vermicomposting into safe environmental practice.

\section{References}

[1] Quintern, M., Seaton, B., Mercer, E. \& Millichamp, P. Industrial scale vermicomposting of pulp and paper mill solids with municipal biosolids and DAF sludge from dairy industries. Appita 66, 290-295 (2013).

[2] BioGro in BioGro NZ Organic Standards (BioGro, New Zealand, 2009).

[3] NZWWA Guidelines for the safe application of biosolids to land in New Zealand (New Zealand Water \& Waste Association, Wellington, New Zealand, 2003).

[4] Edwards, C. A. in Earthworms in Waste and Environmental Management (eds Edwards, C. A. \& Neuhauser, E. F.) 21-31 (SPB Academic Publishing BV, The Hague, The Netherlands, 1988).

[5] Butt, K. R. Utilisation of solid paper-mill sludge and spent brewery yeast as a feed for soil-dwelling earthworms. Bioresource Technology 44, 105107 (1993).

[6] Elvira, C., Goicoechea, M., Sampedro, L., Mato, S. \& Nogales, R. Bioconversion of solid paper-pulp mill sludge by earthworms. Bioresource Technology 57, 173-177 (1996).

[7] Elvira, C., Sampedro, L., Dominguez, J. \& Mato, S. Vermicomposting of wastewater sludge from paper-pulp industry with nitrogen rich materials. Soil Biology and Biochemistry 29, 759-762 (1997).

[8] Elvira, C., Sampedro, L., Benitez, E. \& Nogales, R. Vermicomposting of sludges from paper mill and dairy industries with Eisenia andrei: a pilotscale study. Bioresource Technology 63, 205-211 (1998).

[9] Lazcano, C., Sampedro, L., Zas, R. \& Domínguez, J. Enhancement of pine (Pinus pinaster) seed germination by vermicompost and the role of plant genotype. Compost and digestate: sustainability, benefits, impacts for the environment and for plant production 253-254 (2008).

[10] Lazcano, C., Sampedro, L., Nogales, R. \& Domínguez, J. Paper sludge vermicomposts as amendments into the potting media of peppers (Capsicum annium L. var longum). Compost and digestate: sustainability, benefits, impacts for the environment and for plant production. Proceedings of the international congress CODIS 2008. February 27-29, 2008, Solothurn, Switzerland 211-213 (2008).

[11] Ndegwa, P. M. \& Thompson, S. A. Effects of C-to-N ratio on vermicomposting of biosolids. Bioresource Technology 75, 7-12 (2000). 
[12] Aira, M., Monroy, F. \& Domínguez, J. C to N ratio strongly affects population structure of Eisenia fetida in vermicomposting systems. European Journal of Soil Biology 42, 127-131 (2006).

[13] Edwards, C. A. \& Neuhauser, E. F. Earthworms in waste and environmental management (SPB Academic Publishing, The Hague, The Netherlands (1988).

[14] Arancon, N. Q., Edwards, C. A., Bierman, P., Metzger, J. D. \& Lucht, C. Effects of vermicomposts produced from cattle manure, food waste and paper waste on the growth and yield of peppers in the field. Pedobiologia 49, 297-306 (2005).

[15] Tucker, P. Co-composting paper mill sludge with fruit and vegetable waste. Thesis (2005).

[16] Quintern, M., Wang, H., Magesan, G. \& Slade, A. Vermicomposting primary and secondary solids from the pulp and paper industry (2009).

[17] Quintern, M. Organic waste free pulpmill through vermicomposting - The Kinleith way. New Zealand Land Treatment Collective: Proceedings for the 2011 Annual Conference 32, 84-88 (2011).

[18] Glasner, U. \& Quintern, M. Win Win Win: Biosolids + Pulpmill solids + Compost worms $=$ Fertile soils (The Western Bay Way). New Zealand Land Treatment Collective: Proceedings for the 2011 Annual Conference 32, 96-103 (2011).

[19] Quintern, M. Vermicomposting of lake weeds and pulp \& paper solids for carbon resource recovery for primary sectors. Report LC08/017. Sustainable Farming Fund (2009).

[20] Quintern, M. Full scale vermicomposting and land utilisation of pulpmill solids in combination with municipal biosolids (sewage sludge). 7th International Conference on Waste Management and the Environment 7, 65-76 (2014).

[21] Quintern, M. Industrial scale vermicomposting of municipal biosolids by blending with fibrous industrial waste. Eurasia 2014 Waste Management Symposium 1-9 (2014).

[22] Edwards, C. A. in Vermiculture Technology: Earthworms, Organic Waste, and Environmental Management (eds Edwards, C. A., Arancon, N. Q. \& Sherman, R.) 79-90. CRC Press, (2011).

[23] Quintern, M. Integration of organic pig production within crop rotation: Implications on nutrient losses. Landbauforschung Völkenrode. 31-40 (2005).

[24] Quintern, M. \& Sundrum, A. Ecological risks of outdoor pig fattening in organic farming and strategies for their reduction - Results of a field experiment in the centre of Germany. Agriculture, ecosystems \& environment 117, 238-250 (2006).

[25] NZS Composts, Soil Conditioners and Mulches (New Zealand Standard, NZS 4454:2005, (2005).

[26] Arancon, N. Q. \& Edwards, C. A. in Vermiculture Technology: Earthworms, Organic Waste, and Environmental Management (eds 
Edwards, C. A., Arancon, N. Q. \& Sherman, R.) 129-151 (CRC Press, Taylor \& Francis Group, Boca Raton, London, New York, 2011).

[27] Talarposhti, R. M., Liaghati, H. \& Borojeni, M. R. Effect of organic fertilizers on germination and seedling growth of tomato and suppression of soil borne diseases. Compost and digestate: sustainability, benefits, impacts for the environment and for plant production 27, 259-260 (2008).

[28] Bachman, G. R. \& Metzger, J. D. Growth of bedding plants in commercial potting substrate amended with vermicompost. Bioresource Technology 99, 3155-3161 (2008).

[29] Hidalgo, P. \& Agricultural, M. Earthworm castings increase germination rate and seedling development of cucumber (Office of Agricultural Communications, Mississippi State University, 1999).

[30] Canellas, L. P., Olivares, F. L., Okorokova-Façanha, A. L. \& Façanha, A. R. Humic acids isolated from earthworm compost enhance root elongation, lateral root emergence, and plasma membrane $\mathrm{H}+$-ATPase activity in maize roots. Plant Physiology 130, 1951-1957 (2002).

[31] Rima, J. A. H., Martim, S. A., Dobbss, L. B., Evaristo, J. A. M., et al. Citric acid addition improve humic acids action and change proteins profile from plasma membrane of maize roots. Ciência Rural 41, 614-620 (2011).

[32] Canellas, L. P., Piccolo, A., Dobbss, L. B., Spaccini, R., et al. Chemical composition and bioactivity properties of size-fractions separated from a vermicompost humic acid. Chemosphere 78, 457-466 (2010).

[33] Zandonadi, D. B., Canellas, L. P. \& Façanha, A. R. Indolacetic and humic acids induce lateral root development through a concerted plasmalemma and tonoplast $\mathrm{H}+$ pumps activation. Planta 225, 1583-1595 (2007).

[34] Lazcano, C., Sampedro, L., Zas, R. \& Domínguez, J. Assessment of Plant Growth Promotion by Vermicompost in Different Progenies of Maritime Pine (Pinus pinaster Ait.). Compost Science \& Utilization 18, 111-118 (2010).

[35] Zandonadi, D. B., Santos, M. P., Dobbss, L. B., Olivares, F. L., et al. Nitric oxide mediates humic acids-induced root development and plasma membrane $\mathrm{H}^{+}$-ATPase activation. Planta 231, 1025-1036 (2010).

[36] Roy, S., Arunachalam, K., Dutta, B. K. \& Arunachalam, A. Effect of organic amendments of soil on growth and productivity of three common crops viz. Zea mays, Phaseolus vulgaris and Abelmoschus esculentus. Applied Soil Ecology 45, 78-84 (2010).

[37] Lazcano, C., Revilla, P., Malvar, R. A. \& Domínguez, J. Yield and fruit quality of four sweet corn hybrids (Zea mays) under conventional and integrated fertilization with vermicompost. Journal of the Science of Food and Agriculture 91, 1244-1253 (2011).

[38] Canellas, L. P., Balmori, D. M., Médici, L. O., Aguiar, N. O., et al. A combination of humic substances and Herbaspirillum seropedicae inoculation enhances the growth of maize (Zea mays L.). Plant and Soil 366, 1-14 (2013). 
[39] Chaoui, H., Zibilske, L. \& Ohno, T. Effects of earthworm casts and compost on soil microbial activity and plant nutrient availability. Soil Biology and Biochemistry 35, 295-302 (2003).

[40] Joshi, R., Vig, A. P. \& Singh, J. Vermicompost as soil supplement to enhance growth, yield and quality of Triticum aestivum L.: a field study. International Journal of Recycling of Organic Waste in Agriculture 2, 1-7 (2013).

[41] Arancon, N. Q., Edwards, C. A., Bierman, P., Welch, C. \& Metzger, J. D. Influences of vermicomposts on field strawberries: 1. Effects on growth and yields. Bioresource Technology 93, 145-153 (2004).

[42] Chaoui, H., Edwards, C. A., Brickner, A., Lee, S. S. \& Arancon, N. Q. Suppression of the plant diseases, Pythium (damping-off), Rhizoctonia (root rot) and Verticillium (wilt) by vermicomposts. Brighton crop protection conference pests and diseases 2, 711-716 (2002).

[43] Arancon, N. Q., Galvis, P. A. \& Edwards, C. A. Suppression of insect pest populations and damage to plants by vermicomposts. Bioresource Technology 96, 1137-1142 (2005).

[44] Serfoji, P., Rajeshkumar, S. \& Selvaraj, T. Management of root-knot nematode, Meloidogyne incognita on tomato cv Pusa Ruby. by using vermicompost, AM fungus, Glomus agcoagulans and mycorrhiza helper bacterium, Bacillus coagulans. Journal of Agricultural Technology 6, $37-$ 45 (2010).

[45] Edwards, C. A., Dominguez, J. \& Arancon, N. Q. in Soil zoology for sustainable development in the 21st century (eds Shakir Hanna, S. H. \& Mikhail, W. Z. A.) Cairo, (2004).

[46] Edwards, C. A., Arancon, N. Q., Emerson, E. \& Pulliam, R. Suppressing plant parasitic nematodes and arthropod pests with vermicompost teas. BioCycle 48, 38-39 (2007).

[47] Edwards, C. A., Arancon, N. Q., Vasko-Bennett, M., Askar, A., et al. Suppression of green peach aphid (Myzus persicae) (Sulz.), citrus mealybug (Planococcus citri) (Risso), and two spotted spider mite (Tetranychus urticae) (Koch.) attacks on tomatoes and cucumbers by aqueous extracts from vermicomposts. Crop Protection 29, 80-93 (2010).

[48] Arancon, N. Q., Edwards, C. A., Lee, S. S. \& Yardim, E. Management of plant parasitic nematode populations by use of vermicomposts. Brighton crop protection conference pests and diseases 2, 705-710 (2002).

[49] Sparling, G. \& Schipper, L. Soil quality monitoring in New Zealand: trends and issues arising from a broad-scale survey. Agriculture, Ecosystems and Environment 104, 545-552 (2004).

[50] Bolinder, M. A., Janzen, H. H., Gregorich, E. G., Angers, D. A. \& VandenBygaart, A. J. An approach for estimating net primary productivity and annual carbon inputs to soil for common agricultural crops in Canada. Agriculture, Ecosystems \& Environment 118, 29-42 (2007). 